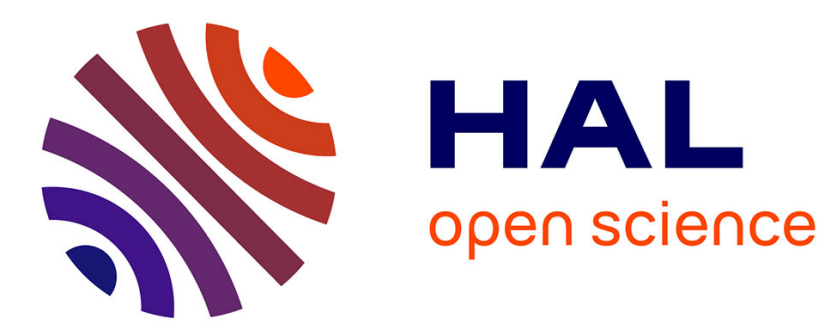

\title{
The Importance of Sexuality for Research on Ethnicity and Nationalism
}

\author{
Michael Stambolis-Ruhstorfer
}

\section{To cite this version:}

Michael Stambolis-Ruhstorfer. The Importance of Sexuality for Research on Ethnicity and Nationalism. Studies in Ethnicity and Nationalism, 2017, 17 (1), pp.44 - 56. 10.1111/sena.12224 . hal02513633

\section{HAL Id: hal-02513633 \\ https://hal.science/hal-02513633}

Submitted on 20 Mar 2020

HAL is a multi-disciplinary open access archive for the deposit and dissemination of scientific research documents, whether they are published or not. The documents may come from teaching and research institutions in France or abroad, or from public or private research centers.
L'archive ouverte pluridisciplinaire HAL, est destinée au dépôt et à la diffusion de documents scientifiques de niveau recherche, publiés ou non, émanant des établissements d'enseignement et de recherche français ou étrangers, des laboratoires publics ou privés. 

Stambolis-Ruhstorfer, Michael. 2017. « The Importance of Sexuality for Research on Ethnicity and Nationalism ». Studies in Ethnicity and Nationalism 17 (1): 44-56. https://doi.org/10.1111/sena.12224.

\title{
AUTHOR'S PRE-PRINT VERSION
}

\section{The Importance of Sexuality for Research on Ethnicity and Nationalism}

\author{
Michael Stambolis-Ruhstorfer* \\ Université Bordeaux Montaigne
}

\begin{abstract}
This article argues for a more systematic inclusion of human sexuality in studies of ethnicity and nationalism. Reviewing key extant social science research on sexuality, it highlights how scholars can leverage its theories, methods, and findings to enhance our understanding of the ways people build imagined ethnic and national communities and draw symbolic boundaries around them. This research reveals that sexuality is not tangential to those activities. Rather, policymakers, religious institutions, local communities, families, and other organizations all participate in more or less obvious ways to define what kinds of sexual desires, behaviours, and identities are acceptable for legitimate citizenship and group belonging. Those decisions have ramifications on both the global scale of international relations and the local scale of personal self-understanding. For these reasons, this article argues that scholarship that elides sexuality may run the risk of painting an incomplete picture of social processes related to ethnicity and nationalism.
\end{abstract}

Key words: Sexuality, Ethnicity, Race, Nationalism, Migration, International Comparison

Marie, a French woman who moved to the United States in her twenties to pursue a career in law, encountered a country with an unfamiliar set of social and political circumstances. It was during this time of discovery, feeling freed from the conventions and expectations of life in France, that she came to realize and accept that she was attracted to women. As she described it, because she came to adopt a gay identity upon moving to the United States, she felt an inseparable connection between her gay sense of self and her host country. For example, she was uncomfortable using the French word 'lesbienne' to describe herself but embraced the English term 'lesbian'. This situation led to an internal struggle between her national and sexual identities. During our interview she described these feelings of conflict:

It bothers me because I came out here so like that part of me was born in America ... I don't know how to explain it. It's almost like the American part of me is gay. Otherwise I don't feel American at all. You know, in a year I can apply for citizenship and I'm like, no way, I really don't want to be an American citizen. I don't feel American at all. I feel French, like incredibly ... but if I think ... I can't reconcile it completely with my sexuality.

Having come to see herself as gay through the language, culture, and politics of the United States, she felt a hard and enduring division along ethnic and national lines in her own biography. The division was caused by her sexuality.

\footnotetext{
* Michael Stambolis-Ruhstorfer is a sociologist and assistant professor of American and Gender Studies at the Université Bordeaux Montaigne. Mobilizing international comparison, his research examines, on the institutional level, the role of "experts" in contentious political debates and, on the individual level, variations in sexual identity across contexts. His work has appeared in the American Journal of Cultural Sociology, the Annual Review of Sociology, and Sociological Forum. michael.stambolis@u-bordeaux-montaigne.fr www.michaelstambolis.com
} 
Excerpted from a study I conducted with French and American lesbians and gay men having migrated to each others' countries (Stambolis-Ruhstorfer 2013), Marie's experience illustrates that analyses of ethnicity are strengthened when they consider sexuality, a dimension that is often overlooked. Research in this field demonstrates that the ways we think about ourselves as sexual beings - the categories we draw on, the language we use, and the norms we follow or break - are necessarily related to how we see ourselves as belonging - or not - to other groups and communities, including nations. In this article, I argue for a broader inclusion and consideration of sexuality in research on ethnicity and nationalism. Indeed, from organizing and channelling reproduction and family to drawing lines that define the symbolic boundaries (Lamont and Molnár 2002) of licit sexual behaviour, sexuality is a major and unavoidable facet of social life. As such, it is integral to the way people construct nationhood and belonging. Yet, because of their presumptions that sexuality is "private" or somehow apolitical, scholars sometimes write it off as at best peripheral and at worse irrelevant to broader social processes.

In what follows, I will first describe several conceptual tools specifically developed for sexuality that can provide opportunities for joint analysis of both intimacy and ethnicity. Then I lay out some of the broader theoretical and political reasons why sexuality has clear implications for social science work on ethnicity and nationalism. Finally, I will review some of the extant literature on sexuality and migration and detail how this kind of work is especially fruitful methodologically for looking at the articulation of national and sexual identity.

\section{Conceptualizing the Culture of Sexuality}

In what kinds of sexual behaviour do people engage? What types of activities, people, or things do they desire? What does all this mean for them and why does it take on that meaning? These are some of the major questions that have animated scientific inquiry about sexuality. Previously relegated to the realm of morality - where religious authorities framed sexuality in terms of sin - or psychology - where mental health experts thought of people in terms of deviant categories, such as 'the homosexual' (Foucault 1984) - some social scientists in the twentieth century strove to draw sexuality away from such judgment and essentialism (Rosario 2002). They sought to study sexuality as a social fact. In order to do so, they argued that we should think about human sexuality in terms of three distinct but interrelated categories: desire, behaviour, and identity (Seidman 2003). For many people, these three elements align with one another. Take for example, a woman who desires men, has sex with men, and identifies herself as heterosexual. However, for others, they may not overlap. An obvious example might be a man who desires women but engages in sex work with men and identifies himself as straight.

By distinguishing along these three lines, we can see that the range of possible desires, behaviours, and identities varies across time and space, revealing how sexuality is socially constructed. We notice, for example, that identity labels such as gay, straight, and bisexual, which dominate in many contemporary Western countries, are non-existent in other places even as people there engage in similar behaviours (Herdt 1997). By contextualizing desire, behaviour, and identity, we can think about the ways in which people grapple with, adopt, reject, or even reconfigure the meaning and practices of sexuality in their specific cultural milieus. For instance, in a study of Chinese men who have sex with men, Wong $(2010,2007)$ finds that they do not simply import and adopt the globally circulated Anglo-American label 'gay'. Rather, they engage in a kind of cultural 'hybridization' that allows them to think about their sexuality and sense of selves through the lens of pre-existing Chinese categories. To combat the stigma associated with the transliteration gei, which they could have chosen to use, men in Hong Kong preferred the term tongzhi ('comrade') that carried positive cultural associations for characterizing their sexual identity. This gave them the opportunity to construct an affirmative sexual identity around a term that resonated within their context.

Social scientists have also demonstrated that socialization teaches people what counts as sexual behaviour, what kinds of things they ought to desire, and how they should think about who they are. They call these patterns 'sexual scripts' (Gagnon and Simon 1974; Kimmel 2007). There are several layers of scripts. At the micro-level, intrapsychic scripts are those in which people develop their sense of what they find erotic and 
arousing. At the next level up, interactional scripts consist of the sexual and romantic roles and ideas exchanged between two or more people. Finally, at the macro level and most germane for our concerns here, cultural scripts are the collective interpretive frameworks we use to think about our sexual identities. They are embedded within institutions, such as schools, churches, and laws. Socializing agents, including parents, educators, peers, and the media deliver them to us. An example of such a script from 1950s white, middleclass, North America was the expectation that sex constituted the sacred domain of a married heterosexual couple and that marriage was preceded by a series of rituals, including dating and engagement.

It is through these cultural scripts, which are necessarily dependent on national and historical context, that we come to learn the range of potential categories we can draw on as we construct our sexual identities. Those interested in analysing sexuality can study these sexual scripts in order to see how they vary across context and how people in different locations embrace, reject, or change them. They may also analyse how institutions use scripts in order to define the set of licit desires, behaviours, or identities. Religious institutions, for example, often set clearly demarcated precepts around sexuality that define what it means to be a member of the community in good standing (Adamczyk and Pitt 2009). Similarly, law is perhaps the most obvious institution that enacts rules about sexuality, such as those banning sex between close kin.

As described in the next section, there is a significant body of research analysing how sexual scripts on the cultural level interact with and define notions of national and ethnic belonging. Some have found, for instance, that sexual minorities, can have a difficult time negotiating their identities as, say, gay or lesbian, in a country, region, or racial/ethnic group where the sexual scripts associated with those desires are non-existent, freighted with accusations of racial or ethnic "inauthenticity," or eroticized in racially essentialized ways (Carrillo and Fontdevila 2014; Chetcuti 2010; Decena 2011; Epstein and Carrillo 2014; Moore 2010; Provencher 2016).

\section{Politicizing Sexuality and Defining the Nation}

Conceptualizing sexuality as multidimensional and scripted helps shed light on its cultural and historical contingency. In so doing, this makes it clear that sexuality is just as much a building block for defining nationhood and belonging as other symbols and institutions, such as language or religion. Sexual identity becomes an integral part of discursive practices that play a role in the construction of a national imagined community (Ayoub 2016; Stychin 2003). As Joane Nagel (2000: 107) has argued, 'racial, ethnic, and national boundaries are also sexual boundaries'. As a result of the overlap between sexuality and other categories, efforts to draw national and ethnic boundaries necessarily create sexual borders and identities. Indeed, in a context of globalization, issues of sexuality and gender, perhaps now more than ever, are cornerstones in constructions of the national (Duyvendak et al. 2016). Because sexuality is tied to deeply intimate experiences of desire and love, but also reproduction, it constitutes an especially potent symbolic and material driver for creating distinctions. This power is reflected in national legal infrastructures that define "sexual citizenship" through policies as far ranging as immigration and asylum to sex education in schools and family welfare regimes (Epstein and Carrillo 2014; Kuhar 2015; Lewis 2014; Lewis and Naples 2014; Stychin 2003). Scholars interested in understanding ethnic and national identity in a specific context should systematically ask themselves: To what degree do legal institutions, politicians, the press, and people's families, churches, and schools conceive of different types of sexualities as belonging to the polity? Which sexualities do they exclude or include and why? In what context are people defining these sexual symbolic boundaries? Answers to these questions, which are ostensibly about sexuality, will always shed light on broader processes of national and ethnic boundary drawing, as the current research shows.

There are compelling examples of political leaders and elites specifically using homosexuality or generally "deviant" sexuality as a tool to starkly distinguish between insiders and outsiders. They can, for example, frame sexual minorities as infiltrated foreigners who threaten social cohesion from within. This kind of framing necessarily shores up heterosexuality as the proper sexuality of the nation. During the late nineteenth century, for example, media and politicians in France, Germany, and the United Kingdom each described homosexuality as a foreign deviance emanating from the other two countries (Tamagne 2004). As a 
result, the rejection of homosexuality was imbued with the power of nationalism and xenophobia. Homosexuals within the country were cast as unpatriotic, foreign others who threatened the strength of the nation. This framing also made it easier for policymakers, families, and other institutions within each country to construct the notion of a virtuous and nationally appropriate sexual behaviour, usually serving the purposes of natalism.

Relatedly, during the $19^{\text {th }}$ century, European colonial empires wielded specific sexualized accounts of the peoples they dominated to better essentialize their 'deviance' and justify colonial 'civilizing' projects (Stoler 1995). These journalistic and academic narratives therefore created racialized scripts about sexual desires and behaviours painting some as 'civilized' and others as 'savage'. This colonial framework shaped how colonizers understood their own sexuality in new and specifically ethnic and national ways relative to the people they were objectifying.

Similar trends continue today. For instance, Russia's recent ban on 'homosexual propaganda' is part of ongoing efforts on the part of officials to frame homosexuality as a deviant sexual practice imported from Western Europe (Persson 2014). In former Soviet countries that joined the European Union, some conservatives fought back against required E.U. anti-discrimination laws protecting sexual minorities arguing that they violated their distinct cultural traditions (O'Dwyer 2012). Romania, for instance, waited until as late as 2001 to repeal laws criminalizing consensual sex between adults of the same sex. Lawmakers' reluctance was rooted in 'nationalistic assumptions' denoting such relationships as 'alien and threatening to the family' (Nachescu 2005:57). Similarly, in the last decade, Uganda has passed radically stringent laws penalizing homosexuality on parliamentarians' justifications that it was an un-African practice imported by rich White Americans hoping to prey on their children (Cheney 2012). In addition to threatening the wellbeing of sexual minorities in these countries, such policies write a national sexual script about culturally appropriate sexual behaviour. In these contexts, people must renounce the possibility of taking on an identity - as well as mask their desires and hide their behaviours - if they want to belong to the nation.

Other countries use homosexuality to define national belonging in precisely the opposite way. Rather than stigmatize homosexuality as foreign, they set acceptance of sexual minorities and sexual liberalism more generally as the requirement for national belonging. Often tied to racist policies and attitudes, this 'homonationalism' (Puar 2007) is a discursive practice whereby politicians co-opt LGBT rights to argue that immigrants - especially Muslims, Africans, and South Asians - are unable to assimilate because of stereotypes about their supposed anti-gay attitudes. In the Netherlands, for instance, policy-makers have constructed tolerance of sexual diversity as part of what it means to be a good Dutch citizen (Mepschen et al. 2010). This makes it easier for nationalistic, anti-Muslim political actors to paint immigrants as homophobic, backward, and intolerant. This stance essentializes both Dutch and Muslim identities. It also puts Muslim people in the Netherlands who experience same-sex desire in a precarious position. This politicization of homosexuality can seem to require that they reject or renounce their ethnic communities in order to gain acceptance, thus pitting them against themselves. Other countries have integrated the promotion of sexual minorities into their foreign policy. For example, depending on the politics of the President at the time, some U.S. embassies fly a rainbow flag, the symbol of the LGBT movement, during the month of June. Rather than promote sexual diversity, however, this practice can stigmatize or alienate local sexual minorities by making them appear aligned with the United States. It can further enhance the idea that homosexuality is 'Western'.

At the same time as a variety of countries wields sexuality politically, on a global scale, gay identity has also become a kind of transnational 'imagined community' (Anderson 2006). Unlike other characteristics that make up a person's sense of self, like race and ethnicity, people in the same family or kinship group do not typically share homosexuality. Rather, attraction to people of the same sex appears to be distributed across social categories like race, class, and region (Gates 2011). Therefore, in order to find solidarity, security, and acceptance, people experiencing attraction to others of the same sex need to forge alliances with others like them in ways that transcend their families and local communities. These efforts have led to the creation of specific "gay" communities of various shapes and sizes with their own cultures.

Scholars have identified the ways in which internationally shared practices, including the same music in bars, expressions such as 'coming out', symbols like the rainbow flag, and international LGBT rights organizations 
contribute to the globalization of this community (Altman 2001). Yet, this globalization - driven in large part by the circulation of ideas, people, and products - is dominated by white middle-class gay men from North America and Europe, which can exclude and marginalize women, working-class people, and people of colour (Adam et al. 1999; Boellstorff 2003). Imbuing globalized gay culture with this particular meaning therefore requires people outside of that dominant group to articulate their homosexuality relative to it (Cantú et al. 2009; Carrillo and Fontedevila 2014; Decena 2011; Provencher 2011; Stambolis-Ruhstorfer and Saguy 2014).

Anthropologists and other scholars studying these processes describe the ways in which people deal with the friction and disconnect between hegemonic, globalized discourses on the one hand, and pre-existing local practices and ideas, on the other (Leap and Boellstorff 2004). In cases as varied as Germany, Quebec, and Indonesia, people in local gay cultures appropriate this globalized culture, by, for example, transforming words, such as 'gay' or 'coming out', into more locally adapted uses. When it is attached to the outside, or the West and the United States in particular, this process can also undermine sexual minorities whose identities and practices were integral parts of their local culture but were not previously labelled as gay (Herdt 1997). By being associated with this transnational gay culture, those local practices can be painted as foreign and lose their previous legitimacy or recognition. These examples highlight how processes of sexual culture formation take place at the intersection of tensions occurring in two simultaneous dimensions: those between foreign and local identity and those between transnational and local 'gay' culture. More generally, the politicization of sexual identity and its relationship to the dynamics of nation-building and globalization underscore the reasons why scholars interested in ethnicity and nationalism should pay closer attention to sexuality.

\section{Migration and Methodological Insights}

Much scholarship at the intersection of sexuality and ethnicity draws on interviews, ethnography, and institutional analysis. In-depth interviews and ethnographic work with migrants - people who were socialized in one context and moved to another - can yield some especially fruitful insights into the articulation between national and sexual identity from the perspective of people living it. Beyond demonstrating that sexuality can be an important factor in motivating people to move and the effects it has on their migration experiences (Cantú et al. 2009), literature in this domain reveals the theoretical and methodological advantages of research on this group. Unlike people who never leave their local context, migrants are particularly sensitive to cultural differences. On the one hand, by moving away from where they grew up, they can become aware of the expectations and norms about sexuality early socialization. On the other hand, they have an outsider's view on the expectations and norms of the people in their new setting. They consciously have to learn the practices of those around them. Because of this unique perspective, they can articulate to researchers the differences they experience across contexts.

Using some of my own research as an example, the vignette in the introduction is taken from a study I conducted in order to understand how French and American gays and lesbians understand their sexual identities (Stambolis-Ruhstorfer 2013). These countries are worth comparing sociologically because of the ways their public policies diverge on questions of social difference - such as those on the basis of race - and political integration (Lamont and Thévenot 2000). I wondered whether American notions of multiculturalism and French notions of universalism had an impact on sexual identity as much as they did on racial and ethnic identity (Alexander 2001; Brubaker 1992) in ways that some scholars had already suggested in noncomparative studies (Provencher 2007). My interviews with French gays and lesbians who moved to the United States and American gays and lesbians who moved to France, revealed that they perceived sharp differences in expectations on sexuality in each country. They found that in France, people generally expected them to downplay their sexual identities in the public sphere or at work. They felt the need to subjugate sexual identity to their national identity. In contrast, while in the United States, they felt pressured to publically claim a gay identity and align themselves with a clear category. Like ethnic or racial identity in the United States, people expected them to hyphenate their sexual and national identities, and think of themselves as, say, gay-Americans. Their experiences migrating between these two countries allowed them to detect these nationally specific cultural-level sexual scripts. 
This research builds on previous interview and ethnographic work on sexual minorities that describes sexual identity as a kind of grammar. Although not analysing international migrants, Brekhus (2003) studies how white men attracted to other men organize their sexual identity in distinct patterns. He posits three ideal types. Some live out their gay identity as a noun; they are a gay. These men live in distinct gay neighbourhoods and organize their social lives exclusively around that identity, attending events and spending time in gay venues and with other gay people. Their sexuality dominates their entire sense of who they are. Others live gayness as a verb; it is something they $d o$. These men lead ostensibly heterosexual lives in suburbs and travel only periodically into the gay neighbourhoods of cities to engage in gay sexual and social behaviour. Their sexuality is only a part of their identity when they flee to gay specific spaces. Otherwise, it is absent. Finally, the last group of men lives their sexual identity as an adjective; they are gay just as much as they are, say, suburban, professional, middle class, or Christian. Their sexual identity is always a part of their sense of self but never more than any other characteristic. These grammars depend on the degree to which a person's sexual identity dominates their other identities and for how long or at what moments in time it does so. For example, for a man who lives his gayness as a verb, his gay identity is highly dominant but only during discreet periods of time, such as on the weekends when he travels to gay venues. At all other times, his gay identity is non-dominant.

Combing this approach with an analysis of race and ethnicity is crucial. Indeed, the ability to choose to engage in a gay identity is shaped by the degree to which one has racial or ethnic privilege. For example, in the United States, the sexual grammar of gay identity is shaped by white racial dominance and therefore has an impact on immigrants and racial minorities. In the instance of Black gay men and women, racism against people of colour within the gay community (Han 2007) and anti-LGBT stigma in the Black community creates specific obstacles for their sexual and racial grammars (Moore 2010). For instance, in predominantly white gay social spaces, they may adopt their gayness as a verb or noun but at the expense of their racial identity. In contrast, in Black social spaces, they may downplay their sexual identities. This reveals that they negotiate their identities depending on the circumstances and the degree of racism and/or homophobia they are experiencing at any give time. Such thinking requires that scholars bring to light the way sexuality intersects with other social locations that constrain and enable people as they imagine the communities to which they feel they belong (Epstein and Carrillo 2014). Connecting sexuality to existing analytical frameworks on ethnic and national identity grammars in the context of immigration, such as that by Unterreiner (2015), is a productive avenue for future work.

Other interview research with migrants shows interesting patterns. Some finds that people experience feelings of conflict between their ethnic and sexual identities. For example, a study on recent male polish migrants moving to the United States shows that they were more likely to feel comfortable taking on a gay identity and living openly as gay men if they moved out of their ethnic neighbourhoods (Izienicki 2009). However, by moving away from their Polish communities, they lost a connection to polish identity and practices but were able to integrate into broader American culture. Research on second-and third-generation Maghrebi (Provencher 2011) and Sub-Saharan (Trawalé and Poiret 2015) immigrants in France, describes some of the challenges these people can face when adopting a gay identity. Being openly gay was sometimes difficult for them within their ethnic communities. At the same time, they also had experiences of rejection among gay identified French people from non-immigrant backgrounds who either assumed they were homophobic, exoticised and eroticised their ethnicity, or rejected them out of racism. Similar dynamics play out for men migrating to and from other contexts, such as between Latin America and the United States (Cantú et al. 2009; Carrillo and Fontedevila 2014). In all of these cases, both sexual and ethnic identities came into play as people constructed their sense of belonging.

Interview and ethnographic research also demonstrates that migration creates specific cultural dynamics for people who are not sexual minorities. For instance, in research on Latino immigrants to the United States and their children, González-López (2005) describes how fathers worried that their daughters would adopt what they perceived as the sexual promiscuity of American women, which would hurt their chances for marriage within the Latino community. As a result, these fathers made efforts to control the romantic practices of their daughters in ways that conformed to expectations about sexual propriety they brought with them from their countries of origin. 
The idea that moving abroad can lead to changes in sexual behaviour in ways that would be unacceptable back home is also present in other work. Walsh (2007), for example, found that straight U.K. immigrants who moved to Dubai for work would meet other European and North American migrants in underground bars. There they would engage in a more promiscuous sexuality than they otherwise would have in their home countries. Being away from the expectations and norms of where they grew up, they engaged in new sexual behaviours in an unfamiliar context. Although British sexual and relationship norms are generally more liberal than those for Dubai natives, they nonetheless carried the weight of certain expectations about appropriate behaviour in terms of flirting and sex outside of long-term relationships. Yet, once these migrants were in a context where socializing agents, such as their parents and friends, who typically enforce familiar sexual scripts were absent, they could create a new set of norms. Walsh attributes this lack of script reinforcement and the underground nature of their bar culture as contributing to a particularly sexually permissive environment, which her respondents called 'debauched'. Indeed, British migrants could go back to the United Kingdom after their time in Dubai with their reputations intact. At the same time, because it brought together 'Westerners' in a comparatively sexually conservative country, engaging in sexual promiscuity provided them with an opportunity to create a sense of collective identity with clear ethnic boundaries, setting them apart from Emiratis in their imaginations.

Whether or not the changes in behaviour Walsh observed were the result of people expressing behaviour they had previously suppressed because of social pressure or the result of people actually discovering new desires in a context with novel norms is unclear. Rejecting the idea that sexual desires exist outside of culture as a kind of biological 'instinct', sexual scripting theory suggests that norms and scripts always shape desires by defining what counts as sexual. In this sense, people do not desire things unless they can conceive of them in the first place. For Walsh's respondents, many only came to desire the 'debauchery' of Dubai once they got there and discovered that such a subculture existed. In any case, that their desire and behaviour for it took place in a 'foreign' country allowed them to preserve their British identities, including the relative sexual reservation expected of them.

By interviewing and observing people who moved across national borders or who were the children of those who did, these studies provide examples of the kinds of insights we can gain into process of identity construction at the intersection of nation and sexuality. These people encounter unique opportunities and challenges that give them insight into cultural expectations about belonging and selfhood. Although their experiences are most immediately relevant for people who migrate, they nonetheless have utility or understanding the norms that shape the lives of those who stay. Research on the intersection of sexuality and ethnicity, however, is not limited to migrants, which is only one area of inquiry that happens to be particularly illustrative. As described in the previous section, scholarship on non-migrants and institutions, such as the law and media, are also fruitful avenues of inquiry.

\section{Conclusion}

To those who have not paid much attention to it, sexuality can seem minor. Yet, like language or belief systems, sexuality is a fundamental part of the human experience and, as such, plays an important - if sometimes difficult to perceive - role in the way we construct our sense of self. Norms and codes about sexual behaviours and identities are important - if not always obvious - parts of the ways racial, ethnic, and national groups construct narratives about who belongs. The above examples of its politicization and its mobilization in research on migrants should provide weight to the argument that sexuality merits our focus. In our various field-sites, we should pay particular attention to political rhetoric and public policies dealing with families, gender, and sexual minorities. Because these issues play an integral role in defining symbolic boundaries, scholarship on ethnicity and nationalism would benefit from their more systematic inclusion

Simply acknowledging the implicit assumptions we build into our research would be helpful. For instance, if we are talking about how marriage and childrearing may help or inhibit immigrant integration, we can acknowledge how the capacity to marry legally or access parenting only applies to certain categories of people. We should also think about asking our respondents to talk about their sexual desires, behaviours, and 
identities. As intimate as they may be, such questions are crucial for understanding their experiences more generally. Their answers will necessarily bring to light important dynamics of inclusion and exclusion that questions about less intimate topics might not reveal.

In sum, sexuality hides in plain sight, making it easy to disregard or subsume under other issues, such as class, religion, and language, with which it interacts. The simultaneous ubiquity and invisibility of sexuality is precisely why it is such a powerful social process. The romantic and sexual lives of the people we study are not tangential, apolitical, or inconsequential; they are central to ethnic and national meaning making.

\section{References}

Adam, Barry D., Jan Willem Duyvendak, and André Krouwel, eds. 1999. The Global Emergence of Gay and Lesbian Politics: National Imprints of a Worldwide Movement. Philadelphia: Temple University Press.

Adamczyk, Amy and Cassady Pitt. 2009. 'Shaping Attitudes about Homosexuality: The Role of Religion and Cultural Context'. Social Science Research 38 (2): 338-51. doi:10.1016/j.ssresearch.2009.01.002.

Alexander, Jeffrey C. 2001. "Theorizing the "Modes of Incorporation": Assimilation, Hyphenation, and Multiculturalism as Varieties of Civil Participation'. Sociological Theory 19 (3): 237-49.

Altman, Dennis. 2001. Global Sex. Chicago: University of Chicago Press.

Anderson, Benedict R. 2006. Imagined Communities: Reflections on the Origin and Spread of Nationalism. Rev. ed. London: Verso.

Ayoub, Phillip M. 2016. When States Come Out: Europe's Sexual Minorities and the Politics of Visibility. New York: Cambridge University Press.

Boellstorff, Tom. 2003. 'Dubbing Culture: Indonesian Gay and Lesbi Subjectivities and Ethnography in an Already Globalized World'. American Ethnologist 30 (2): 225-42. doi:10.1525/ae.2003.30.2.225.

Brekhus, Wayne. 2003. Peacocks, Chameleons, Centaurs: Gay Suburbia and the Grammar of Social Identity. Chicago: University of Chicago Press.

Brubaker, Rogers. 1992. Citizenship and Nationhood in France and Germany. Cambridge, MA: Harvard University Press.

Cantú, Lionel, Nancy A Naples, and Salvador Vidal-Ortiz. 2009. The Sexuality of Migration: Border Crossings and Mexican Immigrant Men. New York: New York University Press.

Carrillo, Héctor and Jorge Fontdevila. 2014. 'Border Crossings and Shifting Sexualities among Mexican Gay Immigrant Men: Beyond Monolithic Conceptions'. Sexualities 17(8):919-38.

Cheney, Kristen. 2012. 'Locating Neocolonialism, "Tradition," and Human Rights in Uganda's "Gay Death Penalty"'. African Studies Review 55 (2): 77-95. doi:10.1353/arw.2012.0031.

Chetcuti, Natacha. 2010. Se dire lesbienne: Vie de couple, sexualité, représentation de soi. Paris: Payot.

Decena, Carlos Ulises. 2011. Tacit Subjects: Belonging and Same-Sex Desire among Dominican Immigrant Men. Durham, NC: Duke University Press. 
Duyvendak, Jan Willem, Peter Geschiere, and Evelien Tonkens, eds. 2016. The Culturalization of Citizenship: Belonging and Polarization in a Globalizing World. London: Palgrave Macmillan UK. Available at: http://link.springer.com/10.1057/978-1-137-53410-1.

Epstein, Steven and Héctor Carrillo. 2014. 'Immigrant Sexual Citizenship: Intersectional Templates among Mexican Gay Immigrants to the USA'. Citizenship Studies 18(3-4):259-76.

Foucault, Michel. 1984. The History of Sexuality: An Introduction. London: Penguin.

Gagnon, John H. and William Simon. 1974. Sexual Conduct: The Social Sources of Human Sexuality. London: Hutchinson.

Gates, Gary J. 2011. How Many People Are Lesbian, Gay, Bisexual and Transgender? University of California Los Angeles: The William's Institute. Retrieved April 4, 2017. Available at: http://escholarship.org/uc/item/09h684x2.

González-López, Gloria. 2005. Erotic Journeys: Mexican Immigrants and Their Sex Lives. Berkeley: University of California Press.

Han, Chong-suk. 2007. 'They Don't Want to Cruise Your Type: Gay Men of Color and the Racial Politics of Exclusion'. Social Identities 13(1):51-67.

Herdt, Gilbert H. 1997. Same Sex, Different Cultures: Gays and Lesbians Across Cultures. Boulder, CO: Westview.

Izienicki, Hubert. 2009. "Not There": The Ostensible Absence of Same-Sex Desire in the Polish Immigrant Community in Chicago'. American Sociological Association Annual Meeting, San Francsico, CA.

Kimmel, Michael S., ed. 2007. The Sexual Self: The Construction of Sexual Scripts. Nashville, TN: Vanderbilt University Press.

Kuhar, Roman. 2015. 'Playing with Science: Sexual Citizenship and the Roman Catholic Church CounterNarratives in Slovenia and Croatia'. Women's Studies International Forum 49:84-92.

Lamont, Michèle and Laurent Thévenot, eds. 2000. Rethinking Comparative Cultural Sociology: Repertoires of Evaluation in France and the United States. Cambridge: Cambridge University Press.

Lamont, Michèle and Virág Molnár. 2002. 'The Study Of Boundaries In The Social Sciences'. Annual Review of Sociology 28(1):167-95.

Leap, William L. and Tom Boellstorff. 2004. Speaking in Queer Tongues: Globalization and Gay Language. Chicago: University of Illinois Press.

Lewis, Rachel A. 2014. “Gay? Prove It": The Politics of Queer Anti-Deportation Activism'. Sexualities 17(8):958-75.

Lewis, Rachel A. and Nancy A. Naples. 2014. 'Introduction: Queer Migration, Asylum, and Displacement'. Sexualities 17(8):911-18.

Mepschen, Paul, Jan Willem Duyvendak, and Evelien H. Tonkens. 2010. 'Sexual Politics, Orientalism and Multicultural Citizenship in the Netherlands'. Sociology 44 (5): 962-79. doi:10.1177/0038038510375740.

Moore, Mignon R. 2010. “Black and Gay in L.A.”: The Relationships Black Lesbians and Gay Men Have with Their Racial and Religious Communities'. In Black Los Angeles: American Dreams and Racial Realities, ed. Darnell Hunt and Ana-Christina Ramon. New York: NYU Press. 
Nachescu, Voichita. 2005. 'Hierarchies of Difference: National Identity, Gay and Lesbian Rights and the Church in Post-Communist Romania'. In Sexuality and Gender in Post-Communist Eastern Europe and Russia, ed. Aleksandar Štulhofer and Theo Sandort. Binghamton, NY: Haworth.

Nagel, Joane. 2000. 'Ethnicity and Sexuality'. Annual Review of Sociology 26 (1): 107-33.

O'Dwyer, Conor. 2012. 'Does the EU Help or Hinder Gay-Rights Movements in Post-Communist Europe? The Case of Poland'. East European Politics 28 (4): 332-52. doi:10.1080/21599165.2012.721094.

Persson, Emil. 2014. 'Banning "Homosexual Propaganda": Belonging and Visibility in Contemporary Russian Media'. Sexuality \& Culture 19 (2): 256-74. doi:10.1007/s12119-014-9254-1.

Provencher, Denis M. 2007. Queer French: Globalization, Language, and Sexual Citizenship in France. Aldershot: Ashgate.

Provencher, Denis M. 2011. 'Coming Out à L'oriental: Maghrebi-French Performances of Gender, Sexuality, and Religion'. Journal of Homosexuality 58 (6-7): 812-33. doi:10.1080/00918369.2011.581924.

Provencher, Denis M. 2016. 'Farid's Impossible “je': Unequal Access to Flexible Language in the Queer Maghrebi French Diaspora'. Journal of Language and Sexuality 5 (1): 113-39. doi:10.1075/jls.5.1.05pro.

Puar, Jasbir K. 2007. Terrorist Assemblages: Homonationalism in Queer Times. Durham, NC: Duke University Press. Available at: http://www.loc.gov/catdir/toc/ecip0716/2007017112.html.

Rosario, Vernon A. 2002. Homosexuality and Science: A Guide to the Debates. Santa Barbara, CA: ABC-CLIO.

Seidman, Steven. 2003. The Social Construction of Sexuality. New York: Norton. Available at: http://www.li.suu.edu/library/circulation/Gurung/soc2370sgSocialConstrCh2Fall10.pdf.

Stambolis-Ruhstorfer, Michael. 2013. 'Labels of Love: How Migrants Negotiate (or Not) the Culture of Sexual Identity'. American Journal of Cultural Sociology 1 (3): 321-45. doi:10.1057/ajcs.2013.11.

Stambolis-Ruhstorfer, Michael and Abigail C. Saguy. 2014. 'How to Describe It? Why the Term Coming Out Means Different Things in the United States and France'. Sociological Forum 29(4):808-29.

Stoler, Ann Laura. 1995. Race and the Education of Desire: Foucault's History of Sexuality and the Colonial Order of Things. Durham, NC: Duke University Press.

Stychin, Carl F. 2003. Governing Sexuality: The Changing Politics of Citizenship and Law Reform. Oxford: Hart.

Tamagne, Florence. 2004. A History of Homosexuality in Europe: Berlin, London, Paris, 1919-1939. New York: Algora.

Trawalé, Damien and Christian Poiret. 2015. 'Black Gay Paris: From Invisibilization to the Difficult Alliance of Black and Gay Politics'. African and Black Diaspora: An International Journal 10 (1): 47-58. doi:10.1080/17528631.2015.1085669.

Unterreiner, Anne. 2015. 'From Registers to Repertoires of Identification in National Identity Discourses: A Comparative Study of Nationally Mixed People in France, Germany, and the United Kingdom'. Studies in Ethnicity and Nationalism 15(2):251-71.

Walsh, Katie. 2007. “It Got Very Debauched, Very Dubai!" Heterosexual Intimacy amongst Single British Expatriates'. Social \& Cultural Geography 8 (4): 507-33. doi:10.1080/14649360701529774. 
Wong, Day. 2007. 'Rethinking the Coming Home Alternative: Hybridization and Coming out Politics in Hong Kong's Anti-homophobia Parades'. Inter-Asia Cultural Studies 8 (4): 600-16. doi:10.1080/14649370701568052.

Wong, Day. 2010. 'Hybridization and the Emergence of "Gay" Identities in Hong Kong and in China'. Visual Anthropology 24 (1-2): 152-70. doi:10.1080/08949468.2011.527810. 